\title{
Use of Prevotella bryantii 25A and a commercial probiotic during subacute acidosis challenge in midlactation dairy cows
}

\author{
J. Chiquette, ${ }^{1}$ M. J. Allison, $†$ and M. Rasmussen¥ \\ *Agriculture and Agri-Food Canada, Dairy and Swine Research and Development Centre, Sherbrooke, Quebec, Canada J1M 0C8 \\ †Department of Animal Science, lowa State University, Ames 50011-3211 \\ $\neq$ Center for Veterinary Medicine, US Food and Drug Administration (FDA), Laurel, MD 20708
}

\section{ABSTRACT}

The objective of this study was to determine the efficacy of Prevotella bryantii 25A as a probiotic during a subacute ruminal acidosis (SARA) challenge using a commercial probiotic as a positive control. Six multiparous ruminally fistulated cows $(\mathrm{BW}=685 \pm$ $65 \mathrm{~kg}$; (mean $\pm \mathrm{SD}$ ) in the mid-phase of lactation $(70$ to 148 DIM) received the following treatments in a replicated $3 \times 3$ Latin square design: (1) total mixed ration (TMR; control, CON), (2) TMR $+2 \mathrm{~g} /$ head per day of a probiotic combination of Enterococcus faecium and Saccharomyces cerevisiae (EFSC), or (3) TMR + Prevotella bryantii 25A. The Latin square consisted of 3 wk of adaptation to the respective treatments during which the animals were fed ad libitum once per day a conventional early-lactation TMR and $1.5 \mathrm{~kg}$ of hay. The adaptation was followed by $4 \mathrm{~d}$ of SARA (no hay) and $10 \mathrm{~d}$ of rest (adaptation diet without probiotics). Dry matter intake and milk production were depressed during SARA (22.0 and $31.8 \mathrm{~kg} / \mathrm{d}$, respectively) compared with adaptation $(24.4$ and $34.0 \mathrm{~kg} / \mathrm{d}$, respectively) and did not recover during rest (22.3 and $30.7 \mathrm{~kg} / \mathrm{d}$, respectively). During SARA, P. bryantii $25 \mathrm{~A}$ had no effect on rumen $\mathrm{pH}$, whereas EFSC reduced the percentage of time with $\mathrm{pH}<6.0(71 \%)$ compared with CON (85\%) and increased maximum $\mathrm{pH}$. The EFSC treatment tended to increase mean $\mathrm{pH}$ over $24 \mathrm{~h}$ (5.65) compared with CON (5.45). Proportion of time with $\mathrm{pH}<5.6$ tended to be lower with EFSC (46\%) than with CON (62\%). Populations of bacteria considered to be the most important cellulose digesters in the rumen (Ruminococcus flavefaciens, Ruminococcus albus, and Fibrobacter succinogenes) were also monitored during these treatments using culture-independent realtime PCR methods. The population of $R$. flavefaciens was similar between the 2 feeding phases, whereas $F$. succinogenes and $R$. albus were lower during SARA

Received March 6, 2012.

Accepted June 22, 2012.

${ }^{1}$ Corresponding author: chiquettej@agr.gc.ca compared with rest. In light of the present study, $P$. bryantii 25A did not prove to be an effective preventative for SARA. The role of EFSC in regulating rumen $\mathrm{pH}$ was confirmed, with a possible effect of maintaining $R$. flavefaciens populations during SARA.

Key words: dairy cow, Enterococcus faecium and Saccharomyces cerevisiae, Prevotella bryantii 25A, subacute ruminal acidosis

\section{INTRODUCTION}

Subacute ruminal acidosis represents one of the most important metabolic disorders in intensive dairy farms and affects rumen fermentation, animal welfare, productivity, and farm profitability (Morgante et al., 2007). This serious digestive disorder occurs when large quantities of rapidly fermentable carbohydrates that exceed the buffering capacity of the rumen are fed to the animals. As a result, rumen VFA as well as lactate may accumulate, causing a decrease in ruminal $\mathrm{pH}$. If the $\mathrm{pH}$ drops below 6.0, fiber digestibility is impaired (Stewart, 1977). When $\mathrm{pH}$ values drop between 5.2 and 5.6, animals may show clinical signs of SARA, causing animal discomfort and decreased production performance (Duffield et al., 2004). In the most acute forms, $\mathrm{pH}$ decreases to values below 5.2 (Mutsvangwa et al., 2002). The problem is accentuated with the lack of a sufficient adaptation period during which the epithelium papillae surface increases for better absorption of VFA. The transition period following parturition, when a change in diet occurs to meet milk production demand, is most critical, although SARA can occur at any time in high-producing dairy cows (Osborne et al., 2004). The economic consequences resulting from poor performance and animal health have made SARA one of the most prevalent animal welfare issues in intensive ruminant production systems (Stone, 2004).

Several authors have induced SARA using a standard feeding protocol to study the consequences of this digestive disorder on different physiological and productive parameters. To the authors' knowledge, this study is the second one along with Chiquette (2009) to use a 
controlled simulation of SARA to understand the role of probiotics in the regulation of rumen fermentation during this critical period.

Prevotella bryantii 25A was previously selected and isolated for its ability to grow rapidly on starch and to produce end products other than lactate (mainly succinate and propionate; Rodriguez, 2003). In a preliminary study where $P$. bryantii $25 \mathrm{~A}$ was introduced in the rumen of 3 goats submitted to a lactic acidosis challenge, Rodriguez (2003) observed that ruminal pH values were lower in the control animals following the lactic acidosis challenge. Rumen lactate concentrations peaked at $80 \mathrm{~m} M$ after $8 \mathrm{~h}$ and remained elevated in control animals, whereas a maximal lactate concentration of $15 \mathrm{~m} M$ was recorded in treated animals during the 4 to $8 \mathrm{~h}$ of starch exposure. A rapid decrease to less than $3 \mathrm{~m} M$ was also observed in treated animals after $12 \mathrm{~h}$.

Prevotella bryantii 25A increased ruminal fermentation products and milk fat concentration in a previous study (Chiquette et al., 2008). Because signs of SARA were not observed in either treated or control cows, no conclusions could be made about protection against acidosis by $P$. bryantii $25 \mathrm{~A}$.

The commercial probiotic Probios TC (Chr. Hansen, Milwaukee, WI) is a combination of 2 strains of Enterococcus faecium with the yeast Saccharomyces cerevisiae. This probiotic mixture controlled ruminal $\mathrm{pH}$ decrease in SARA-challenged late-lactating cows (Chiquette, 2009) and more recently in SARA-challenged earlylactating cows (J. Chiquette, unpublished data), as well as in early-lactating cows not challenged with SARA (Nocek et al., 2002). It also increased milk production in early-lactating cows (Nocek et al., 2003; Nocek and Kautz, 2006). The objective of the present project was, therefore, to evaluate the ability of $P$. bryantii $25 \mathrm{~A}$ to protect against the symptoms of acidosis in SARAchallenged lactating dairy cows, using the commercial Probios TC as a positive control.

\section{MATERIALS AND METHODS}

\section{Animals, Feeding, and Sampling Procedure}

All animals in this experiment were cared for according to the standards set by the Canadian Council on Animal Care (CCAC, 1993). Six multiparous, ruminally fistulated cows $(\mathrm{BW}=685 \pm 65 \mathrm{~kg}$, mean $\pm \mathrm{SD})$ in the mid-phase of lactation (70 to 148 DIM) received the following treatments in a replicated $3 \times 3$ Latin square design: (1) TMR (control, CON); (2) TMR + 2 g/ head per day of a probiotic combination (Probios TC; Chr. Hansen), providing $5 \times 10^{9}$ cells/dose of 2 lactic acid-producing strains of Enterococcus faecium and $2 \times$
$10^{9}$ cells/dose of Saccharomyces cerevisiae (EFSC); or (3) TMR $+25 \mathrm{~mL} /$ head per day of Prevotella bryantii $25 \mathrm{~A}, 2 \times 10^{11}$ cells/dose. Each experimental period of the Latin square consisted of 3 wk of adaptation to the respective treatments during which the animals were fed ad libitum once per day at $0900 \mathrm{~h}$ a conventional early-lactation TMR (Table 1) and $1.5 \mathrm{~kg}$ of dry hay. The adaptation phase was followed by $4 \mathrm{~d}$ of lactic acidosis challenge (as described below), which was followed by $10 \mathrm{~d}$ of rest during which the animals were back to the adaptation diet but without probiotic supplementation (Table 2). The TMR was formulated to meet the MP, net energy, mineral, and vitamin requirements for lactating Holstein cows weighing $625 \mathrm{~kg}$ and producing $40 \mathrm{~kg}$ of $3.9 \% \mathrm{FCM}$ when consuming $24 \mathrm{~kg}$ of DM/d (NRC, 1989).The composition of the diets during the project is given in Table 2. Preparation and handling of $P$. bryantii 25 A before use have been described previously (Chiquette et al., 2008). The probiotic powder EFSC was kept at $4^{\circ} \mathrm{C}$, following manufacturer's recommendations, until ready to use. The viability and counts of probiotics were checked at the beginning of the project and at the beginning of each experimental period.

The procedure described by Keunen et al. (2002) was followed for induction of SARA. During the $4 \mathrm{~d}$ of induction of SARA, $30 \%$ of ad libitum intake of the TMR was replaced with wheat and barley pellets (WBP) containing $50 \%$ ground wheat and $50 \%$ ground barley. The cows were fed $2 \mathrm{~kg}$ of the TMR at $0700 \mathrm{~h}$ and two-thirds of the WBP at $0900 \mathrm{~h}$. Between 1100 and $1130 \mathrm{~h}$, the cows were given access to their TMR. At $1300 \mathrm{~h}$, they received the remainder of the WBP. From 1500 to $1530 \mathrm{~h}$, the cows again had access to their TMR. At $1700 \mathrm{~h}$, the remainder of the TMR was fed to the animals. Grain pellets that were not consumed

Table 1. Composition of the TMR

\begin{tabular}{lc}
\hline Composition & $\% \mathrm{DM}$ \\
\hline Grass silage & 19.7 \\
Corn silage & 19.7 \\
Corn grain & 40.8 \\
Soybean meal $^{\text {Protein supplement }}{ }^{1}$ & 15.1 \\
Vitamin-mineral mixture $^{2}$ & 2.0 \\
Calcium carbonate $^{2}$ & 1.7 \\
\hline
\end{tabular}

${ }^{1}$ Protein supplement contained the following ingredients: corn distillers grains $(25 \%)$, wheat distillers grains $(15 \%)$, canola meal $(15 \%)$, and SoyPLUS (45\%; West Central Cooperative, Ralston, IA).

${ }^{2}$ Vitamin-mineral mixture contained the following major minerals (g/ $\mathrm{kg}$ ): $\mathrm{Ca}$ (95), P (55), Mg (55), Na (130), Cl (150), K (14), and S (21); the following minor minerals $(\mathrm{mg} / \mathrm{kg})$ : Fe $(2,745)$, Mn $(2,065)$, $\mathrm{Zn}(3,000), \mathrm{Cu}$ (495), I (69), Co (33), and Se (20); and the following vitamins $(\mathrm{UI} / \mathrm{kg})$ : vitamin A $(501,859)$, vitamin D $(65,000)$, and vita$\min \mathrm{E}(2,600)$. 
Table 2. Composition of the diets during the study (\% MS)

\begin{tabular}{lccc}
\hline Diet & Adaptation & SARA & Rest \\
\hline TMR & 95 & 70 & 95 \\
Hay & 5 & - & 5 \\
Wheat and barley pellets $(50 / 50)$ & - & 30 & - \\
\hline
\end{tabular}

within $1 \mathrm{~h}$ of feeding were placed into the rumen via the fistula. No hay was provided during the week of the challenge. Feed intake was recorded daily, and samples of TMR and WBP were collected weekly and pooled by experimental period.

During the $4 \mathrm{~d}$ of SARA induction and on $\mathrm{d} 7 \mathrm{of}$ rest, $1 \mathrm{~L}$ of rumen content was sampled for determination of VFA, lactate, and $\mathrm{NH}_{3}-\mathrm{N}$, at $0700 \mathrm{~h}$ (before feeding) as well as at $1,2,3$, and $4 \mathrm{~h}$ following the first introduction of WBP in the rumen. Rumen content samples were squeezed through 4 layers of cheesecloth to remove large feed particles. Samples for $\mathrm{NH}_{3}-\mathrm{N}$ were kept at $-20^{\circ} \mathrm{C}$. Samples for VFA and lactate were acidified before freezing [ $5 \mathrm{~mL}$ of filtered rumen fluid and $1 \mathrm{~mL}$ of $\mathrm{H}_{2} \mathrm{SO}_{4}(0.5 \mathrm{M})$ ] and then kept at $-20^{\circ} \mathrm{C}$ until further analyses. Rumen samples (solid + liquid) for bacterial quantification were taken at $0700 \mathrm{~h}$ and $3 \mathrm{~h}$ post-WBP, on d 3 of SARA, and on d 7 of rest. Those samples were kept unfiltered at $-80^{\circ} \mathrm{C}$ until further analysis.

\section{Analyses of Feed Nutrients}

The nutrient composition of the TMR, WBP, and hay (Table 3) was determined as follows: DM content was determined by oven drying at $105^{\circ} \mathrm{C}$ for $48 \mathrm{~h}$ (AOAC, 1990, 930.15), and the ash content was determined by incineration at $550^{\circ} \mathrm{C}$ overnight. Total $\mathrm{N}$ was measured by thermal conductivity (Leco model FP-428 Nitrogen Determinator; Leco Corp., St. Joseph, MI). The concentration of NDF was determined as described by Van Soest et al. (1991), without the use of sodium sulfite and with the inclusion of heat-stable $\alpha$-amylase. It was expressed inclusive of residual ash.

The NDF procedure was adapted for use in an Ankom $^{200}$ Fiber Analyzer (Ankom Technology Corp., Fairport, NY). The ether extract content of the TMR, silages, and orts was measured using a Soxtec HT 6 apparatus (Tecator; Fisher Scientific, Montreal, QC, Canada) according to the method of the Association of Official Analytical Chemists (AOAC, 1990, 920.39).

\section{Feed Intake, Milk Production, and Composition}

Feed intake and refusals as well as milk production were recorded daily. Milk samples were taken on 4 consecutive milkings during the last week of adapta- tion, during the challenge, and rest. Milk samples were kept at $4^{\circ} \mathrm{C}$ using bronopol as preservative and shipped weekly to Valacta Inc. (DHI organization responsible for milk recording in Sainte-Anne-de-Bellevue, QC, Canada). The contents of milk fat, protein, and ureanitrogen was determined using a near-infrared analyzer (Foss Electric A/S, Hillerød, Denmark) according to AOAC (1990).

\section{Ruminal $\mathrm{pH}$}

Ruminal pH was recorded every 10 min over a 24-h period during each of the 3 wk of adaptation, continuously during the $4 \mathrm{~d}$ of SARA induction, and over a 24-h period on d 5 of rest. A submersible electrode (Cole Parmer, Mississauga, ON, Canada) was inserted through the rumen fistula and suspended in the ventral sac of the rumen. The electrode was protected by a wire shield and attached to a $0.5-\mathrm{kg}$ weight. Electrodes were connected to a $\mathrm{pH}$ meter with an RS-232 recorder output (Oakton 1000; Fisher Scientific, Nepean, ON, Canada), which was connected to a computer with the Balance Talk software program (Labtronics Inc., Guelph, ON, Canada). The electrodes were calibrated with $\mathrm{pH} 4$ and 7 buffer solutions (Fisher Scientific, Nepean, ON, Canada) before insertion into the rumen and were not withdrawn during $\mathrm{pH}$ measurement unless questionable readings were recorded. Calibration was checked at the end of data collection. No drifts in calibration were noted.

Table 3. Nutrient composition (\% DM)

\begin{tabular}{lrrr}
\hline $\begin{array}{l}\text { Nutrient } \\
\text { composition }\end{array}$ & TMR & WBP $^{1}$ & Hay \\
\hline DM & 92.4 & 88.0 & 90.0 \\
CP & 17.2 & 14.3 & 7.4 \\
aNDF & 26.4 & 18.3 & 68.4 \\
ADF & 17.1 & 6.4 & 42.2 \\
Ether extract & 4.1 & 1.9 & 1.8 \\
NSC $^{3}$ & 46.5 & 62.3 & 17.3 \\
\hline
\end{tabular}

${ }^{1} \mathrm{WBP}=$ Wheat and barley pellets $(50 / 50)$.

${ }^{2}$ aNDF $=$ NDF assayed with a heat-stable amylase.

${ }^{3} \mathrm{NSC}=100-(\mathrm{NDF}+$ ether extract $+\mathrm{CP}+$ ash $)$. 


\section{Ruminal VFA, Lactate, and Ammonia-N Determination}

Upon thawing, VFA samples were centrifuged $\left(29,000 \times g\right.$ for $20 \mathrm{~min}$ at $\left.4^{\circ} \mathrm{C}\right)$. Approximately $1 \mathrm{~mL}$ of an ion-exchange resin (Dowex 50 WX8-100; SigmaAldrich, St. Louis, MO) was added for purification, incubated for $10 \mathrm{~min}$, and then samples were filtered through a $0.22-\mu \mathrm{m}$ syringe filter. Subsamples $(0.5 \mu \mathrm{L})$ were analyzed using a Hewlett-Packard model 6890 gas chromatograph (Hewlett-Packard, Agilent Technology Canada Inc., Mississauga, ON, Canada). The column used was a DB-FFAP $(25 \mathrm{~m} \times 0.32 \mathrm{~mm} \times 0.50 \mu \mathrm{m}$; Agilent Technologies Inc., Santa Clara, CA). The temperatures of the injector and detector were 250 and $300^{\circ} \mathrm{C}$, respectively.

D,L-Lactate was analyzed using the colorimetric assay of Taylor (1996). For the determination of $\mathrm{NH}_{3}-\mathrm{N}$ concentration, filtered rumen content was centrifuged $\left(17,750 \times \mathrm{g}\right.$ for $5 \mathrm{~min}$ at $\left.4^{\circ} \mathrm{C}\right)$, and the supernatant was analyzed using the phenol-hypochlorite reaction (Weatherburn, 1967) with volumes adapted for microplates.

\section{Quantification of Bacteria}

Bacterial Strains and Growth. Strains were obtained from the American Type Culture Collection (ATCC, Manassas, VA). The following strains of rumen bacteria were used as reference strains: Ruminococcus flavefaciens (strain C52, ATCC 49949), Ruminococcus albus (strain 7, ATCC 27210), Fibrobacter succinogenes (strain GC5, ATCC 51216), and Megasphaera elsdenii (ATCC 25940). They were cultured in a rumen fluidbased medium as previously reported (Klieve et al., 1989). For M. elsdenii, the medium used was reinforced clostridial medium BD218081 (Fisher Scientific Ltd., Ottawa, ON, Canada), as recommended by ATCC, and did not contain rumen fluid.

The procedure for DNA extraction and purification from pure bacterial cultures and mixed ruminal content is described in Chiquette et al. (2007). The only modification is that DNA from rumen fluid samples and from bacterial cultures was extracted in duplicate instead of triplicate.

Real-Time Primers, Probes, and Operating Conditions. The development and application of a real-time Taq nuclease assay for the enumeration of $R$. flavefaciens, $R$. albus, F. succinogenes, and M. elsdenii have been reported previously (Ouwerkerk et al., 2002; Chiquette et al., 2007). Quantification of DNA of each bacterial species in total rumen DNA was performed using an ABI 7500 Fast Real-Time PCR System (PE Applied BioSystems, Foster City, CA). Optimal
PCR reactions $(10-\mu \mathrm{L}$ total volume) contained $5 \mu \mathrm{L}$ of TaqMan Universal PCR Master Mix (PE Applied Biosystems), $2 \mu \mathrm{L}$ of diluted DNA, forward primers, reverse primers, and probes at the following concentrations: 300, 300, and $200 \mathrm{n} M ; 900,900$, and $200 \mathrm{n} M$; 300, 300, and $200 \mathrm{n} M$; and 300, 300, and $200 \mathrm{n} M$ for $R$. flavefaciens, R. albus, F. succinogenes, and M. elsdenii, respectively. Analyses were performed in triplicate. The cycling parameters were $20 \mathrm{~s}$ at $95^{\circ} \mathrm{C}$, followed by $40 \mathrm{cy}-$ cles of $3 \mathrm{~s}$ at $95^{\circ} \mathrm{C}$ and $30 \mathrm{~s}$ at $60^{\circ} \mathrm{C}$. Real-time TaqMan assays were calibrated by the cycle threshold method (Heid et al., 1996). Serial dilutions of purified genomic DNA from reference strains cited previously were used to construct species-specific calibration curves. The standard curves for each primer/probe set were linear (correlation coefficients $>0.998$ ), with target cell concentrations ranging from $7.6 \times 10^{3}$ to $7.6 \times 10^{7}, 8.6 \times$ $10^{2}$ to $8.6 \times 10^{6}, 1.3 \times 10^{2}$ to $1.3 \times 10^{6}$, and $1.1 \times 10^{4}$ to $1.1 \times 10^{8}$ cells $/ \mathrm{mL}$ for $R$. flavefaciens, $R$. albus, F. succinogenes, and $M$. elsdenii, respectively. Amplification efficiency, calculated from the slopes, ranged from 77 to $93 \%$. A standard curve was made for each analysis run. The number of cells in fresh overnight cultures was determined by microscopic enumeration using a Petroff-Hausser counting chamber, at $\times 400$ magnification and diluted in the Norris-Powell solution (Norris and Powell, 1961), as described by Koch (1994). Counts were repeated 4 times for each bacterial group. The quantity of bacterial groups was expressed as cells per milliliter of ruminal content. Possible PCR inhibitors such as reagents used during nucleic acid extraction or co-purified components from rumen content were tested by serially diluting several unknown samples and assessing the efficiency of amplification (Nolan et al., 2006).

\section{Statistics}

Variables were summarized to 1 data point per cow per period and statistically analyzed according to a $3 \times$ 3 Latin square design balanced for residual effects, with cow, period, and treatment as fixed factors. Phases, days within SARA phase, and pre- and postfeeding times were analyzed as repeated measurements. The MIXED procedure of SAS (SAS Institute, 2002) was used for all analyses. For all variables, adaptation and rest phases were compared with the SARA phase. Within SARA, data from d 1 to 4 were analyzed for linear and quadratic effects using polynomial contrasts. When the effect of probiotics was significant, both $P$. bryantii 25A and EFSC were further compared with CON, using Dunnett's correction. For bacterial populations, the rumen was only sampled on d 3 of SARA; results from pre- and postfeeding were compared dur- 
ing both SARA and rest. Lactate concentration and bacterial population data were log transformed to obtain a normal distribution and homogeneous residual error and reconverted to millimolar concentration and cells per milliliter, respectively, for presentation in the tables. Least squares means are associated with confidence intervals instead of standard errors of the means for these 2 variables. Significance was declared at $P \leq$ 0.05 , and trends were accepted if $P \leq 0.10$.

\section{RESULTS AND DISCUSSION}

\section{DMI, Milk Production, and Composition}

Dry matter intake was depressed during SARA (22.0 $\mathrm{kg} / \mathrm{d})$ compared with adaptation $(24.4 \mathrm{~kg} / \mathrm{d} ; P<$ 0.001 ) and did not recover to adaptation level during rest $(22.3 \mathrm{~kg} / \mathrm{d}$; Table 4$)$. During the $4 \mathrm{~d}$ of SARA, DMI decreased linearly and in a quadratic manner, the most important decrease being recorded on the second day of SARA, followed by somewhat constant DMI for the remaining SARA phase (Table 4). Depression of DMI is commonly reported in grain-induced SARA (Gozho et al., 2005, 2006; Fairfield et al., 2007). As rumen $\mathrm{pH}$ decreases following a meal rich in carbohydrates, the first response of the animal is a depression in feed intake (Oetzel et al., 2007). In a previous study with late-lactation cows, DMI during adaptation was only $20.7 \mathrm{~kg} / \mathrm{d}$, as opposed to $24.4 \mathrm{~kg} / \mathrm{d}$ in the present study, and DMI was not decreased during SARA (Chiquette, 2009). It may well be that along with the dietary makeup, the DMI of cows before the induction of SARA could affect the severity of depression observed during SARA, similarly to the premise brought forward for milk fat depression during SARA by Gozho et al. (2007). It has been proposed that the decreased DMI observed during SARA is a consequence of decreased rumen motility (Kleen et al., 2003). The increased osmolarity of rumen content due to a reduced absorption of VFA through the epithelium would be responsible for decreased rumen motility (Owens et al., 1998).

Very few studies have reported production parameters during the recovery phase following SARA induction. Krause and Oetzel (2005) reported a $25 \%$ decrease in DMI during SARA (2 d of SARA) and recovery to baseline level during rest ( $2 \mathrm{~d}$ of measurements). The short phase of rest $(2 \mathrm{~d}$ as opposed to $10 \mathrm{~d}$ in the present study) during which DMI was recorded could explain the difference between the Krause and Oetzel (2005) study and the present study. Probiotics had no effect on DMI independently of the feeding phase considered.

Similarly to DMI, milk production decreased during SARA $(31.8 \mathrm{~kg} / \mathrm{d})$ compared with the adaptation phase $(34.0 \mathrm{~kg} / \mathrm{d} ; P=0.003)$ and did not recover during rest

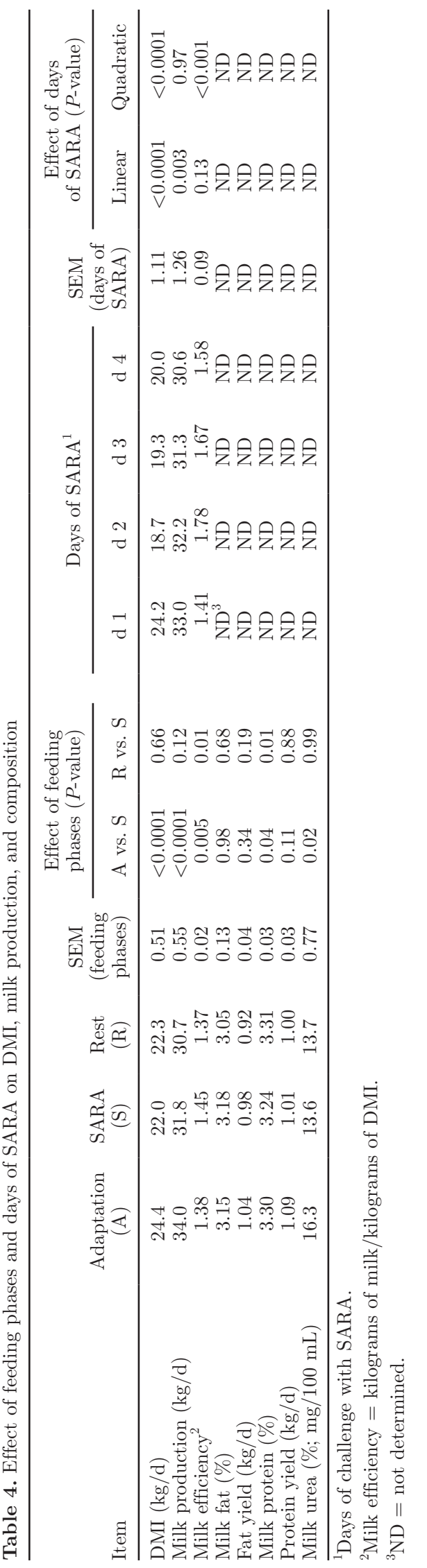

Journal of Dairy Science Vol. 95 No. 10, 2012 
$(30.7 \mathrm{~kg} / \mathrm{d})$. During the $4 \mathrm{~d}$ of SARA, milk production decreased linearly (Table 4 ).

The depression in milk production recorded from the present study $(2.2 \mathrm{~kg} / \mathrm{d})$, during induced SARA, was less than what was reported by Stone $(1999 ; 3 \mathrm{~kg} /$ cow per day), Krause and Oetzel $(2005 ; 3.5 \mathrm{~kg} / \mathrm{d})$, and Khafipour et al. (2009a; $3.3 \mathrm{~kg} / \mathrm{d})$. These latest values of milk depression compare better with that recorded during the rest phase of the present study $(3.3 \mathrm{~kg} / \mathrm{d})$.

Similarly to DMI, milk production was not affected by probiotics at any of the feeding phases. This could be due to the lactation stage of the animals. Studies where probiotics improved milk production were with early-lactation cows (Nocek and Kautz, 2006) but this could not be tested here because the Latin square design of the present study extended over 4 mo.

Milk efficiency increased during SARA $(1.45 \mathrm{~kg}$ of milk/kg of DMI), compared with that during adaptation $(1.38 \mathrm{~kg}$ of milk $/ \mathrm{kg}$ of DMI; $P=0.005)$ or rest $(1.37 \mathrm{~kg}$ of milk $/ \mathrm{kg}$ of DMI; $P=0.01)$. Similar observations can be made from data reported by Krause and Oetzel (2005). The increased milk efficiency during SARA followed a quadratic curve (i.e., reaching a peak on d 2 and decreasing thereafter). Probiotics did not affect milk efficiency in any feeding phases.

Milk protein concentration slightly decreased during SARA $(3.24 \%)$ compared with that during adaptation $(3.30 \% ; P=0.04)$ and rest $(3.31 \% ; P=0.01)$. This decrease in protein concentration during SARA is slightly less $(2 \%)$ than the $3 \%$ reported by Stone (1999). Milk protein yield tended to decrease during SARA and remained low during rest (Table 4). A similar pattern in milk protein yield between pre-SARA, SARA, and recovery was reported by Krause et al. (2009).

Milk urea concentration also decreased during SARA $(13.6 \mathrm{mg} / 100 \mathrm{~mL})$ compared with adaptation (16.3 $\mathrm{mg} / 100 \mathrm{~mL} ; P=0.02)$ and did not recover to adaptation level during rest $(13.7 \mathrm{mg} / 100 \mathrm{~mL})$. Enemark (2008) reported that normal urea concentration should be between 3 to $5 \mathrm{~m} M$, but $<3 \mathrm{~m} M$ during SARA. In the present study, milk urea concentrations during SARA and adaptation corresponded to 3 and $2 \mathrm{mM}$, respectively. Milk was only sampled on $2 \mathrm{~d}$ during SARA so that linear and quadratic effects could not be determined.

Milk fat percentage and milk fat yield were not affected by SARA. Although milk fat depression is often associated with SARA, it is not always the case. Alzahal et al. (2010) reported that the effect of ruminal $\mathrm{pH}$ on milk fat is inconsistent in the literature. Allen (1997) summarized the association between ruminal $\mathrm{pH}$ and milk fat concentration from 23 studies and concluded that ruminal $\mathrm{pH}$ explained $39 \%$ of the variation in milk fat percentage. More recently, Enemark et al. (2004) reported that correlation coefficients between ruminal $\mathrm{pH}$ and milk fat synthesis in cows over 30 DIM were only 0.305 . An explanation brought forward by Krause and Oetzel (2005) is that a short duration of SARA (4 d) is not sufficiently long to allow the metabolic change to occur. Krause et al. (2009) reported that decreased milk fat percentage probably occurs during repeated bouts of SARA. Probiotics had no effect on the concentration of milk constituents independently of the feeding phases considered.

\section{Rumen $\mathrm{pH}$}

Characteristics of $\mathrm{pH}$ measured during adaptation weeks and SARA weeks showed that SARA conditions were successfully induced with the grain challenge model used. All pH characteristics were indicative of greater acidic conditions in the rumen during SARA (Table 5). Time with rumen $\mathrm{pH}$ below 5.6 corresponded to 5,13 , and $4 \mathrm{~h}$ during adaptation, SARA, and rest, respectively, which represented ruminal conditions slightly more acidic than the ones reported by Krause et al. (2009), where rumen $\mathrm{pH}$ was below 5.6 for 2 $\mathrm{h}$ pre-SARA, $11 \mathrm{~h}$ during SARA, and $3 \mathrm{~h}$ during recovery. These conditions can be considered as severe SARA when compared with most of the SARA challenges reported in the literature (Gozho et al., 2007; Khafipour et al., 2009a,c). For most of the rumen pH characteristics of the present study, a linear increase toward more acidic conditions occurred with days of SARA. An increase was observed in the percentage of time during which rumen $\mathrm{pH}$ was below 5.2 from $\mathrm{d} 1$ (18\%) to 4 (40\%), corresponding to 4 to $9.6 \mathrm{~h} / \mathrm{d}$ from d 1 to 4 , respectively. During the rest phase that followed $\mathrm{SARA}$, rumen $\mathrm{pH}$ recovered to adaptation values. This suggests that the rest phase was sufficiently long to allow the recovery of normal fermentation.

Probiotics had no effect on rumen $\mathrm{pH}$ characteristics during the adaptation or the phase of rest when compared with CON. During SARA, EFSC reduced the percentage of time during which $\mathrm{pH}$ was $<6.0(71 \%)$ compared with CON $(85 \% ; P=0.03)$ and increased the maximum $\mathrm{pH}$ recorded $(P=0.05)$. Enterococcus faecium and Saccharomyces cerevisiae tended to increase mean $\mathrm{pH}$ recorded over $24 \mathrm{~h}$ (5.65) compared with CON $(5.45 ; P=0.10 ;$ Table 6$)$. Although not significant, a decrease was observed in the proportion of time with $\mathrm{pH}$ below 5.6 when the animals received EFSC (46\%) compared with CON (62\%). In a previous study with late-lactation cows (4) in a Latin square design, including a phase with SARA challenge (Chiquette, 2009), EFSC also tended to increase rumen $\mathrm{pH}$ during SARA (5.84) when compared with the control $(5.41 ; P=0.06)$ and increased the nadir $\mathrm{pH}$ (5.02) compared with the 
control $(4.43 ; P=0.05)$. As in the present study, the proportion of time during which $\mathrm{pH}$ was below 5.6 was numerically but not statistically lower with EFSC $(28 \%)$ compared with the control $(66 \%)$. This probiotic mixture was used by Nocek et al. (2002), who suggested that at the level of $10^{5}$ cells $/ \mathrm{mL}$ of rumen fluid, EFSC increased mean rumen $\mathrm{pH}$.

Prevotella bryantii $25 \mathrm{~A}$ had no effect on any of the rumen $\mathrm{pH}$ characteristics recorded during SARA. In a previous study (Chiquette et al., 2008), P. bryantii 25 A decreased ruminal lactate concentrations in dairy cows during 7 wk postpartum. Because signs of SARA were not observed in either treated or control cows in that study, no conclusions could be made about possible protection against acidosis by $P$. bryantii. It appears from the present results that $P$. bryantii $25 \mathrm{~A}$ cannot prevent or mitigate SARA symptoms from challenged dairy cows.

\section{Rumen VFA, Lactate, and Ammonia}

Total VFA concentration was greater during SARA $(106 \mathrm{mM})$ than during rest $(77 \mathrm{mM}$; Table 7). Except for butyrate, the proportion of each individual VFA was also affected by the feeding phase. Proportions of propionate and valerate were greater during SARA compared with rest, whereas proportions of acetate and iso-acids were less during SARA than during rest. The relative change in the proportion of each VFA is consistent with the greater proportion of rapidly fermentable carbohydrate during SARA than during rest and is similar to the change in the proportion of VFA during a SARA challenge, reported by Blanch et al. (2009). In the present study, it is interesting to observe the dynamic of the fermentation pattern during the 4 d of SARA with a rapid modification within $24 \mathrm{~h}$ of SARA induction and stabilization thereafter. Valerate proportions, on the other hand, increased linearly from d 1 to 4 of SARA.

No effect of probiotics was observed on total VFA concentration or on the proportion of each individual VFA during SARA or rest. This is consistent with results from a previous study (Chiquette, 2009) where EFSC was given to late-lactating cows submitted to a SARA challenge. Very little data exists in the literature on the effect of this particular combination of probiotics over the proportion of ruminal VFA. In a study with steers fed $87 \%$ rolled barley, Beauchemin et al. (2003) used a similar combination of EFSC but with only 1 strain of E. faecium as opposed to 2 strains in the present study and reported no effect of the probiotic on the proportion of individual VFA or total VFA. Similarly to a previous study with early-lactating dairy cows (Chiquette et al., 2008), P. bryantii 25A had no 
Table 6. Effects of probiotics on rumen $\mathrm{pH}$ characteristics during SARA

\begin{tabular}{|c|c|c|c|c|c|c|}
\hline \multirow[b]{2}{*}{$\mathrm{pH}$} & \multicolumn{3}{|c|}{ Probiotic $^{1}$} & \multirow[b]{2}{*}{ SEM } & \multicolumn{2}{|c|}{$P$-value } \\
\hline & $\mathrm{CON}$ & ES & $25 \mathrm{~A}$ & & ES vs. CON & $25 \mathrm{~A}$ vs. $\mathrm{CON}$ \\
\hline Mean & 5.45 & 5.65 & 5.55 & 0.06 & 0.10 & 0.50 \\
\hline $\mathrm{Min}^{2}$ & 4.74 & 4.83 & 4.73 & 0.10 & 0.74 & 1.00 \\
\hline $\mathrm{Max}^{3}$ & 6.33 & 6.59 & 6.41 & 0.07 & 0.05 & 0.62 \\
\hline Pct $<6.0^{4}$ & 84.7 & 71.1 & 79.1 & 3.24 & 0.03 & 0.39 \\
\hline Pct $\geq 5.6,<6.0$ & 22.2 & 24.5 & 22.1 & 3.79 & 0.87 & 1.00 \\
\hline Pct $<5.6$ & 62.3 & 46.3 & 57.0 & 5.32 & 0.11 & 0.70 \\
\hline Pct $\geq 5.2,<5.6$ & 27.8 & 24.1 & 26.9 & 2.78 & 0.56 & 0.96 \\
\hline Pct $<5.2$ & 34.9 & 22.0 & 30.1 & 5.70 & 0.24 & 0.78 \\
\hline
\end{tabular}

effect on propionate proportions. This is particularly intriguing because $P$. bryantii $25 \mathrm{~A}$ was selected for its ability to produce succinate in vitro as the main end product of carbohydrate fermentation. Succinate is known to be readily metabolized to propionate in the rumen environment (Blackburn and Hungate, 1963) and, therefore, is rarely present in appreciable amounts. It was not quantified in the present study.

Lactate concentrations increased during SARA (1.31 $\mathrm{m} M)$ compared with rest $(0.41 \mathrm{~m} M$; Table 7$)$ but were kept far below detrimental levels characteristics of acute lactic acidosis (40 $\mathrm{mM}$; Owens et al. 1998). The evolution of lactate concentration from d 1 to 4 of SARA followed a quadratic curve, peaking on d 2 of SARA and decreasing thereafter to the level of $\mathrm{d} 1$. The highest lactate concentration was recorded $2 \mathrm{~h}$ after the morning meal during SARA $(3.9 \mathrm{~m} M)$ compared with prefeeding ( $0.3 \mathrm{~m} M ; P<0.001$; data not shown). During rest, the highest lactate concentrations were recorded $1 \mathrm{~h}$ after the morning meal $(1.3 \mathrm{~m} M)$ and decreased thereafter to values not different from prefeeding concentration ( $0.2 \mathrm{mM}$; data not shown). A similar trend and lactate levels were observed by Blanch et al. (2009) during and after a SARA challenge.

Although lactate concentrations were numerically lower with EFSC during SARA, P. bryantii 25A and EFSC had no effect on lactate concentrations during SARA or rest. No interaction existed between probiotic and sampling times or days of SARA. The previous decrease in lactate concentrations when early-lactating cows received $P$. bryantii from wk 1 to 6 postpartum (Chiquette et al., 2008) was not reproduced under short-term SARA challenge. Khafipour et al. (2009c), who studied rumen microbiome composition using 2 nutritional models of SARA, identified Prevotella spp. as being potential probiotics to use in the prevention of SARA, based on the high abundance of Prevotella spp. in alfalfa pellet-induced SARA. In light of the present study, the particular strain of P. bryantii 25A, which has been shown to decrease lactate concentrations in the rumen of early-lactating cows, did not prove effective in decreasing lactate concentrations or controlling rumen $\mathrm{pH}$ when added to the rumen of cows experiencing an induced SARA challenge.

Given that EFSC affected rumen $\mathrm{pH}$, one would expect an effect of EFSC on total VFA or on lactate concentration. The difference in sampling frequencies between these variables might explain the absence of such effect. Indeed, $\mathrm{pH}$ was recorded continuously over a 24-h period as opposed to finite VFA and lactate samplings concentrated in the hours (1 to 4) following feeding, where most of the fermentative activity occurs. It could also be that under SARA conditions, where lactate concentration is kept under control by the activity of lactate-utilizing bacteria, the addition of E. faecium, which is believed to boost the population of lactate-utilizing bacteria, does not give additional advantage.

Ammonia-N was lower during SARA (133 mg/100 $\mathrm{mL})$ than during rest $(186 \mathrm{mg} / 100 \mathrm{~mL} ; P<0.001$; Table 7). A drastic and linear decrease in $\mathrm{NH}_{3}-\mathrm{N}$ concentration occurred on the first $3 \mathrm{~d}$ of SARA $(P<$ 0.001; Table 7), possibly caused by the detrimental effect of low $\mathrm{pH}$ on the activity of proteolytic bacteria. Khafipour et al. (2009b) reported a similar decrease in $\mathrm{NH}_{3}-\mathrm{N}$ concentration in the rumen $(-20 \%)$ as rumen $\mathrm{pH}$ decreased. Generally probiotics had no effect on $\mathrm{NH}_{3}-\mathrm{N}$ concentrations during SARA; however, on the first day of SARA, P. bryantii 25A increased $\mathrm{NH}_{3}-\mathrm{N}$ $(313 \mathrm{mg} / \mathrm{L})$ compared with $\mathrm{CON}(232 \mathrm{mg} / \mathrm{L})$ at all sampling times $(P=0.04$; Figure 1$)$. A similar increase in $\mathrm{NH}_{3}-\mathrm{N}$ was observed with $P$. bryantii $25 \mathrm{~A}$ in a previous study (Chiquette et al., 2008) and is consistent with the known proteolytic activity of this bacterium. 


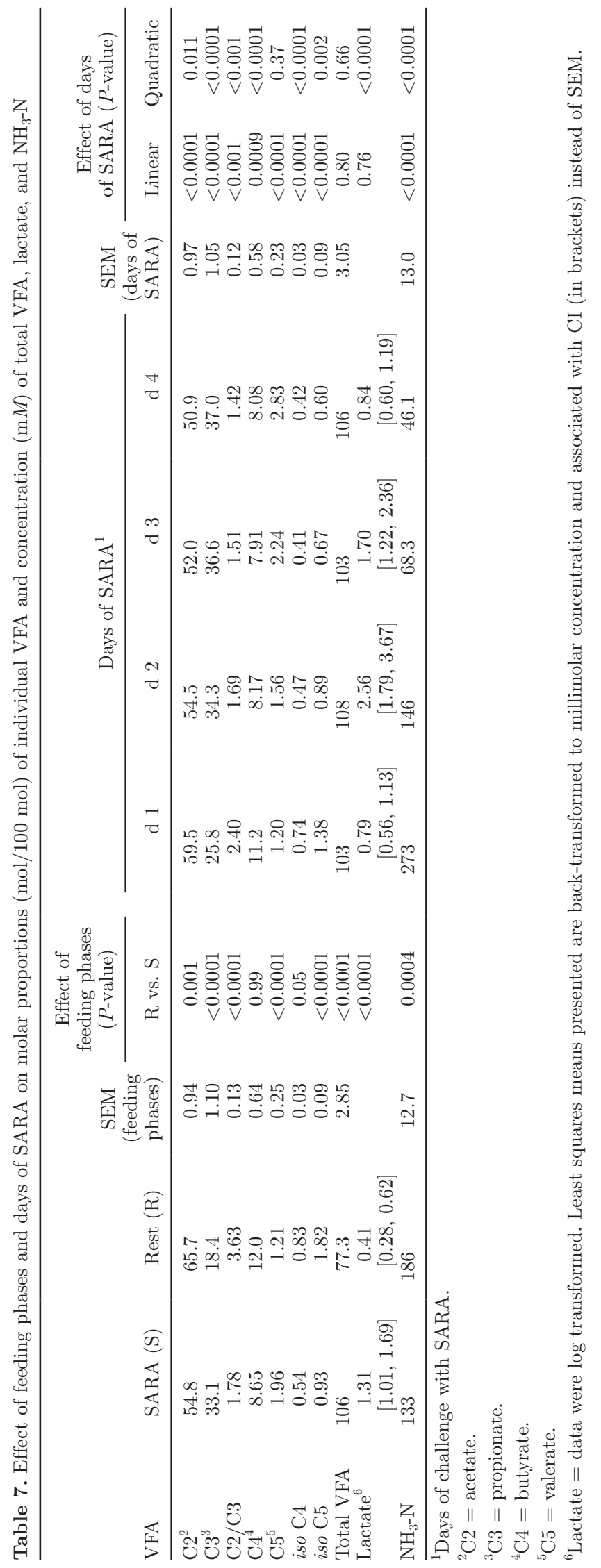

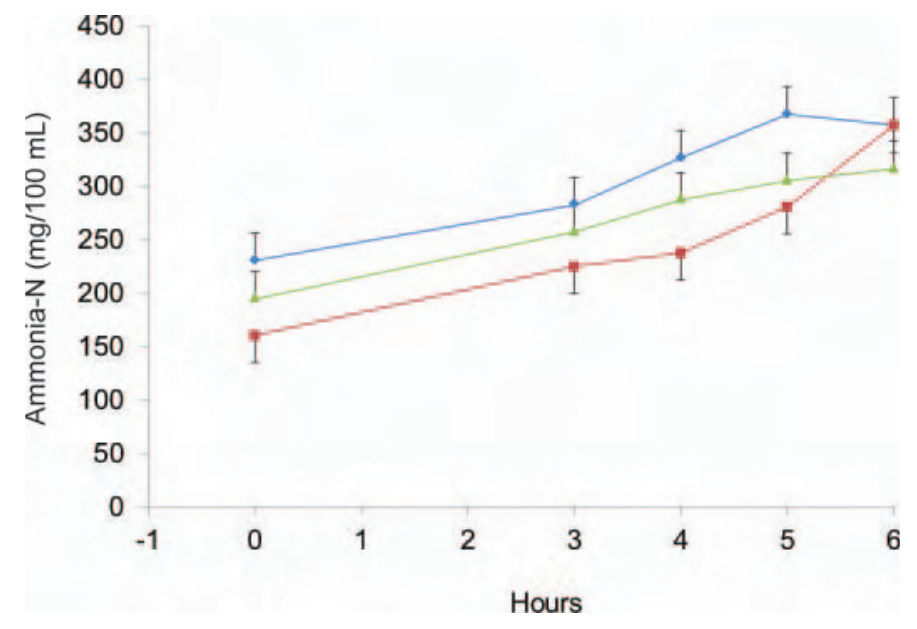

Figure 1. Ruminal ammonia- $\mathrm{N}$ concentrations on d 1 of SARA challenge in dairy cows receiving Prevotella bryantii $25 \mathrm{~A}(25 \mathrm{~mL} / \mathrm{head}$ per day, containing $2 \times 10^{11}$ cells; $) ; 2 \mathrm{~g} /$ head per day of a probiotic combination (Probios TC; Chr. Hansen, Milwaukee, WI), providing 5 $\times 10^{9}$ cells/dose of 2 lactic acid-producing strains of Enterococcus faecium and $2 \times 10^{9}$ cells/dose of Saccharomyces cerevisiae (EFSC; $\mathbf{\Delta}$ ); or no probiotics (control; $\mathbf{\square})$. Prevotella bryantii versus control: $P=0.04$. Error bars represent SE. Color version available in the online PDF.

\section{Bacterial Populations}

Populations of $R$. flavefaciens were similar between the 2 feeding phases (average population $=2.6 \times 10^{8}$ cells $/ \mathrm{mL}$ ), whereas $F$. succinogenes and $R$. albus populations were lower $(P<0.001)$ during SARA compared with rest (Table 8$)$. Cellulolytic bacteria are known to be sensitive to low rumen $\mathrm{pH}$; however, it appears from the results of the present study that $R$. flavefaciens would be more resistant to low rumen $\mathrm{pH}$ than other cellulolytics. Results from a previous study (Chiquette, 2009 ) also showed greater populations of $R$. flavefaciens $\left(3.3 \times 10^{8}\right.$ cells $\left./ \mathrm{mL}\right)$ compared with $R$. albus $\left(5.1 \times 10^{6}\right.$ cells $/ \mathrm{mL})$ or $F$. succinogenes $\left(5 \times 10^{5}\right.$ cells $\left./ \mathrm{mL}\right)$ during a SARA challenge. On the other hand, M. elsdenii increased 10-fold during SARA $\left(1.49 \times 10^{7}\right.$ cells $\left./ \mathrm{mL}\right)$ compared with rest $\left(0.12 \times 10^{7}\right.$ cells $\left./ \mathrm{mL} ; P<0.001\right)$. Blanch et al. (2009) also observed an important increase in $M$. elsdenii population during an acidosis challenge (104 ng/mL) compared with prechallenge (0.087 ng/ $\mathrm{mL}$ ), although in their study, the difference was not significant. As long as M. elsdenii can metabolize the lactate produced during the fermentation of grain, no accumulation of lactate occurs. The increase in M. elsdenii during SARA seems to have prevented lactate accumulation, as shown by low levels of ruminal lactate during SARA.

Sampling time (pre-feed vs. $3 \mathrm{~h}$ post-feed) had no effect during rest, for all bacterial species under study. However, during SARA, all bacterial populations in- 


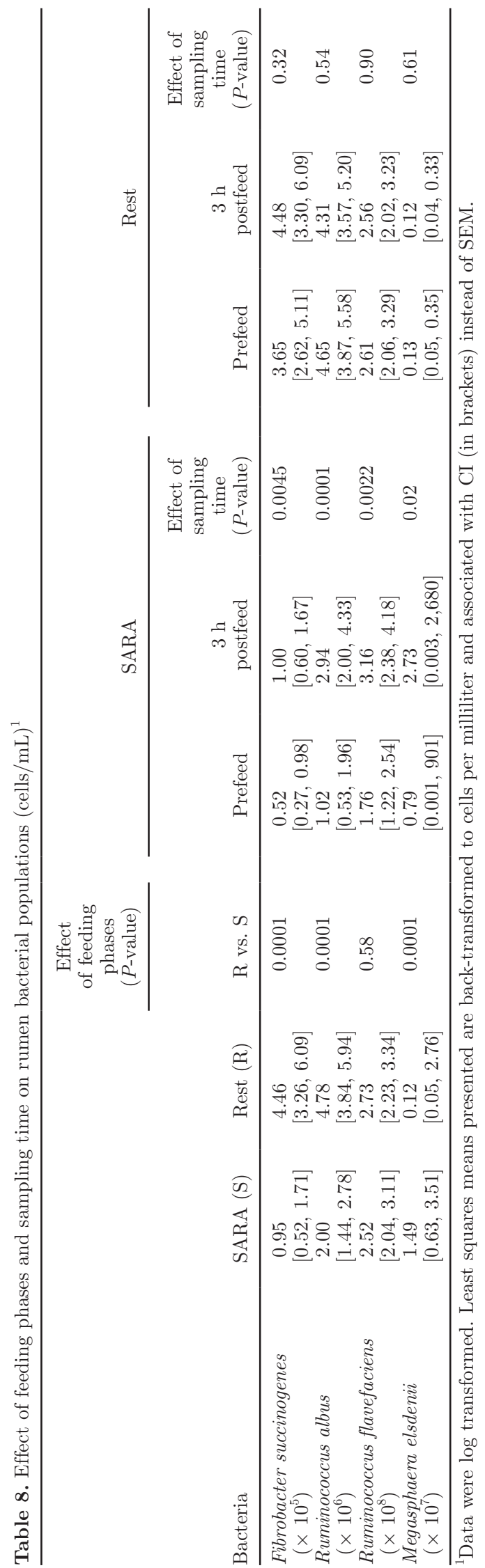

creased significantly $3 \mathrm{~h}$ post-feed compared with prefeed (Table 8).

Enterococcus faecium and Saccharomyces cerevisiae increased the population of $R$. flavefaciens during SARA $\left(3.64 \times 10^{8}\right.$ cells $\left./ \mathrm{mL}\right)$ compared with $P$. bryantii $\left(2.28 \times 10^{8}\right.$ cells $\left./ \mathrm{mL} ; P=0.05\right)$ and $\mathrm{CON}\left(1.92 \times 10^{8}\right.$ cells $/ \mathrm{mL} ; P=0.01$; data not shown). Addition of probiotics had no effect on the other cellulolytic bacterial populations during SARA and rest phases.

\section{CONCLUSIONS}

The role of EFSC in regulating rumen $\mathrm{pH}$ was confirmed, with a possible effect at maintaining $R$. flavefaciens populations during SARA. In light of the present study, the particular strain of $P$. bryantii $25 \mathrm{~A}$, which has been shown to decrease lactate concentration in the rumen of early-lactating cows, did not prove effective when added to the rumen of cows experiencing an induced SARA challenge.

\section{ACKNOWLEDGMENTS}

The authors acknowledge the technical work of F. Markwell, L. Marier, M.-C. Benoit, C. Richer (all of Agriculture and Agri-Food Canada, Sherbrooke), and A. Payet-Maugeron (School of Engineers in Agriculture, Ésitpa, Val de Reuil, France). We thank C. Bolduc, R. Lanctôt, and M. Poitras (all of Agriculture and AgriFood Canada) for animal care. The statistical support of S. Méthot (Agriculture and Agri-Food Canada, Sherbrooke) is also greatly acknowledged. Finally, thanks to Chr. Hansen (S. A. Graham, Milwaukee, WI) for the provision of EFSC. This project was partly funded by Dairy Farmers of Canada (Ottawa, ON, Canada) and Agriculture and Agri-Food Canada (Ottawa, ON, Canada).

\section{REFERENCES}

Allen, M. S. 1997. Relationship between fermentation acid production in the rumen and the requirement for physically effective fiber. J. Dairy Sci. 80:1447-1462.

Alzahal, O., M. M. Or-Rashid, S. L. Greenwood, and B. W. McBride. 2010. Effect of subacute acidosis on milk fat concentration, yield and fatty acid profile of dairy cows receiving soybean oil. J. Dairy Res. 77:376-384.

AOAC (Association of Official Analytical Chemists). 1990. Official Methods of Analysis. 15th ed. AOAC, Arlington, VA.

Beauchemin, K. A., W. Z. Yang, D. P. Morgavi, G. R. Ghorbani, W. Kautz, and J. A. Z. Leedle. 2003. Effects of bacterial direct-fed microbials and yeast on site and extent of digestion, blood chemistry, and subclinical ruminal acidosis in feedlot cattle. J. Anim. Sci. $81: 1628-1640$

Blackburn, T. H., and R. E. Hungate. 1963. Succinic acid turnover and propionate production in the rumen. Appl. Microbiol. 11:132-135.

Blanch, M., S. Calsamiglia, N. DiLorenzo, A. DiCostanzo, S. Muetzel, and R. J. Wallace. 2009. Physiological changes in rumen fermenta- 
tion during acidosis induction and its control using a multivalent polyclonal antibody preparation in heifers. J. Anim. Sci. 87:17221730 .

CCAC (Canadian Council on Animal Care). 1993. Guide to the Care and Use of Experimental Animals. E. D. Olfert, B. M. Cross, and A. A. McWilliams, ed. Vol. 1. 2nd ed. CCAC, Ottawa, ON, Canada. $</$ edb $>$

Chiquette, J. 2009. Evaluation of the protective effect of probiotics fed to dairy cows during a subacute ruminal acidosis challenge. Anim. Feed Sci. Technol. 153:278-291.

Chiquette, J., M. J. Allison, and M. A. Rasmussen. 2008. Prevotella bryantii $25 \mathrm{~A}$ used as a probiotic in early-lactation dairy cows: Effect on ruminal fermentation characteristics, milk production, and milk composition. J. Dairy Sci. 91:3536-3543.

Chiquette, J., G. Talbot, F. Markwell, N. Nili, and R. J. Forster. 2007. Repeated ruminal dosing of Ruminococcus flavefaciens NJ along with a probiotic mixture in forage or concentrate-fed dairy cows: Effect on ruminal fermentation, cellulolytic populations and in sacco digestibility. Can. J. Anim. Sci. 87:237-249.

Duffield, T., J. C. Plaizier, A. Fairfield, R. Bagg, G. Vessie, P. Dick, J. Wilson, J. Aramini, and B. W. McBride. 2004. Comparison of techniques for measurement of rumen $\mathrm{pH}$ in lactating dairy cows. J. Dairy Sci. 87:59-66.

Enemark, J. M. D. 2008. The monitoring, prevention and treatment of sub-acute ruminal acidosis (SARA): A review. Vet. J. 176:32-43.

Enemark, J. M. D., R. J. Jørgensen, and N. B. Kristensen. 2004. An evaluation of parameters for the detection of subclinical rumen acidosis in dairy herds. Vet. Res. Commun. 28:687-709.

Fairfield, A. M., J. C. Plaizier, T. F. Duffield, M. I. Lindinger, R. Bagg, P. Dick, and B. W. McBride. 2007. Effects of a prepartum administration of a monensin controlled release capsule on rumen $\mathrm{pH}$, feed intake, and milk production of transition dairy cows. J. Dairy Sci. 90:937-945.

Gozho, G. N., D. O. Krause, and J. C. Plaizier. 2006. Rumen lipopolysaccharide and inflammation during grain adaptation and subacute ruminal acidosis in steers. J. Dairy Sci. 89:4404-4413.

Gozho, G. N., D. O. Krause, and J. C. Plaizier. 2007. Ruminal lipopolysaccharide concentration and inflammatory response during grain-induced subacute ruminal acidosis in dairy cows. J. Dairy Sci. 90:856-866.

Gozho, G. N., J. C. Plaizier, D. O. Krause, A. D. Kennedy, and K. M. Wittenberg. 2005. Subacute ruminal acidosis induces ruminal lipopolysaccharide endotoxin release and triggers an inflammatory response. J. Dairy Sci. 88:1399-1403.

Heid, C. A., J. Stevens, K. J. Livak, and P. M. Williams. 1996. Realtime quantitative PCR. Genome Res. 6:986-994.

Keunen, J. E., J. C. Plaizier, L. Kyriazakis, T. F. Duffield, T. M. Widowski, M. I. Lindinger, and B. W. Mc Bride. 2002. Effects of a subacute ruminal acidosis model on the diet selection of dairy cows. J. Dairy Sci. 85:3304-3313.

Khafipour, E., D. O. Krause, and J. C. Plaizier. 2009a. A grain-based subacute ruminal acidosis challenge causes translocation of lipopolysaccharide and triggers inflammation. J. Dairy Sci. 92:10601070.

Khafipour, E., D. O. Krause, and J. C. Plaizier. 2009b. Alfalfa pelletinduced subacute ruminal acidosis in dairy cows increases bacterial endotoxin in the rumen without causing inflammation. J. Dairy Sci. $92: 1712-1724$.

Khafipour, E., S. Li, J. C. Plaizier, and D. O. Krause. 2009c. Rumen microbiome composition determined using two nutritional models of subacute ruminal acidosis. Appl. Environ. Microbiol. 75:7115-7124.

Kleen, J. L., G. A. Hooijer, J. Rehage, and J. P. T. M. Noordhuizen. 2003. Subacute ruminal acidosis (SARA): A review. J. Vet. Med. A Physiol. Pathol. Clin. Med. 50:406-414.

Klieve, A. V., J. F. Hudman, and T. Bauchop. 1989. Inducible bacteriophages from ruminal bacteria. Appl. Environ. Microbiol. 55:1630-1634.
Koch, A. L. 1994. Growth measurement. Pages 249-277 in Methods for General and Molecular Bacteriology. P. Gerhardt, R. G. E. Murray, W. A. Wood, and N. R. Krieg ed. American Society for Microbiology, Washington, DC.

Krause, K. M., D. V. Dhuyvetter, and G. R. Oetzel. 2009. Effect of a low-moisture buffer block on ruminal $\mathrm{pH}$ in lactating dairy cattle induced with subacute ruminal acidosis. J. Dairy Sci. 92:352-364.

Krause, K. M., and G. R. Oetzel. 2005. Inducing subacute ruminal acidosis in lactating dairy cows. J. Dairy Sci. 88:3633-3639.

Morgante, M., C. Stelletta, P. Berzaghi, M. Gianesella, and I. Andrighetto. 2007. Subacute ruminal acidosis in lactating cows: An investigation in intensive Italian dairy herds. J. Anim. Physiol. Anim. Nutr. (Berl.) 91:226-234.

Mutsvangwa, T., J. D. Walton, J. C. Plaizier, T. F. Duffield, R. Bagg, P. Dick, G. Vessie, and B. W. McBride. 2002. Effects of a monensin controlled-release capsule or premix on attenuation of subacute ruminal acidosis in dairy cows. J. Dairy Sci. 85:3454-3461.

NRC. 1989. Nutrient Requirements of Dairy Cattle. 6th rev. ed. National Academy of Sciences, Washington, DC.

Nocek, J. E., and W. P. Kautz. 2006. Direct-fed microbial supplementation on ruminal digestion, health, and performance of pre- and postpartum dairy cattle. J. Dairy Sci. 89:260-266.

Nocek, J. E., W. P. Kautz, J. A. Z. Leedle, and J. G. Allman. 2002. Ruminal supplementation of direct-fed microbials on diurnal $\mathrm{pH}$ variation and in situ digestion in dairy cattle. J. Dairy Sci. $85: 429-433$.

Nocek, J. E., W. P. Kautz, J. A. Z. Leedle, and E. Block. 2003. Directfed microbial supplementation on the performance of dairy cattle during the transition period. J. Dairy Sci. 86:331-335.

Nolan, T., R. E. Hands, W. Ogunkolade, and S. A. Bustin. 2006. SPUD: A quantitative assay for the detection of inhibitors in nucleic acid preparations. Anal. Biochem. 351:308-310.

Norris, K. P., and E. O. Powell. 1961. Improvements in determining total counts of bacteria. J. R. Microsc. Soc. 80:107-119.

Oetzel, G. R., K. M. Emery, W. P. Kautz, and J. E. Nocek. 2007. Direct-fed microbial supplementation and health and performance of pre- and postpartum dairy cattle: A field trial. J. Dairy Sci. 90:2058-2068.

Osborne, J. K., T. Mutsvangwa, O. Alzahal, T. F. Duffield, R. Bagg, P. Dick, G. Vessie, and B. W. McBride. 2004. Effects of monensin on ruminal forage digestibility and total tract diet digestibility in lactating dairy cows during grain-induced subacute ruminal acidosis. J. Dairy Sci. 87:1840-1847.

Ouwerkerk, D., A. V. Klieve, and R. J. Forster. 2002. Enumeration of Megasphaera elsdenii in rumen contents by real-time Taq nuclease assay. J. Appl. Microbiol. 92:753-758.

Owens, F. N., D. S. Secrist, W. J. Hill, and D. R. Gill. 1998. Acidosis in cattle - A review. J. Anim. Sci. 76:275-286.

Rodriguez, F. 2003. Control of lactate accumulation in ruminants using Prevotella bryantii. PhD Thesis. Iowa State University, Ames.

SAS Institute. 2002. SAS Statistical Analysis System. Release 9.1. SAS Institute Inc., Cary, NC.

Stewart, C. S. 1977. Factors affecting the cellulolytic activity of rumen contents. Appl. Environ. Microbiol. 33:497-502.

Stone, W. C. 1999. The effect of subclinical ruminal acidosis on milk components. Pages 40-46 in Proc. 61st Cornell Nutr. Conf. Feed Manuf., Ithaca, NY. Cornell University Press, Ithaca, NY.

Stone, W. C. 2004. Nutritional approaches to minimize subacute ruminal acidosis and laminitis in dairy cattle. J. Dairy Sci. 87(E. Suppl.):E13-E26.

Taylor, K. A. C. C. 1996. A simple colorimetric assay for muramic acid, lactic acid, glyceraldehyde, acetaldehyde and formaldehyde. Appl. Biochem. Biotechnol. 56:49-58.

Van Soest, P. J., J. B. Robertson, and B. A. Lewis. 1991. Methods for dietary fiber, neutral detergent fiber, and nonstarch polysaccharides in relation to animal nutrition. J. Dairy Sci. 74:3583-3597.

Weatherburn, M. W. 1967. Phenol-hypochlorite reaction for determination of ammonia. Anal. Chem. 39:971-974. 